\title{
Internal control of accounting of fixed assets in accordance with the new standards
}

\author{
T. V. Zyryanova ${ }^{1}$, E. V. Manakova ${ }^{2 凶}$ \\ ${ }^{1}$ Ural State Agrarian University, Ekaterinburg, Russia \\ ${ }^{2}$ Ural Institute of Management - the branch of the Russian Presidential Academy of National \\ Economy and Public Administration, Ekaterinburg, Russia \\ ${ }^{\otimes}$ E-mail: manakova.elena@inbox.ru
}

Abstract. The purpose. Study of the peculiarities of the organization of the internal control system of fixed assets in order to reduce the risks of ineffective use and theft. Research methods. Analyzed normative acts, explanations of regulatory authorities, judicial practice. Particular attention is paid to the analysis of federal accounting standards governing the accounting of fixed assets, which come into effect from 2022. Results. Changes in regulations governing the procedure for conducting accounting and tax accounting require adjustments and methods of verification by internal controllers. Fixed assets are components of the material and technical base of the enterprise, allow increasing sales, producing quality products and increasing attractiveness in the eyes of investors. The introduction of new accounting standards, as well as the strengthening of administration by the regulatory authorities, require a revision of internal local documents and changes to the internal control methods. The directions of the organization of internal control of fixed assets, practical examples of incorrect reflection in the accounting of assets and the consequences leading to additional taxes are considered. The risks of theft and ineffective use of fixed assets arise from both managers and employees of the enterprise. Properly organized internal control will help identify fraud patterns and reduce the risks of damage to the enterprise. The paper proposes step-by-step algorithms for organizing internal control for the main business operations associated with the use of fixed assets. Namely, the algorithm for checking the accrued depreciation, repair costs, documents confirming the liquidation of fixed assets. Errors made in the formation of the initial cost can lead to a distortion of the cost, the book value of fixed assets and lead to an incorrect calculation of income tax and property tax of organizations. Keywords: internal control, fixed assets, accounting standards, tax control, acquisition cost, fraud, risks.

For citation: Zyryanova T. V., Manakova E. V. Internal control of accounting of fixed assets in accordance with the new standards // Agrarian Bulletin of the Urals. 2022. No. 02 (217). Pp. 82-89. DOI: 10.32417/1997-48682022-217-02-82-89. (In Russian.)

Date of paper submission: 21.12.2021, date of review: 14.01.2022, date of acceptance: 21.01.2022.

\section{Introduction}

One of the important components of the material and technical base of the organization are the fixed assets that are necessary to improve the efficiency of the enterprise. The use of fixed assets in the activities of the enterprise gives the business stability and attractiveness in the eyes of potential investors.

By purchasing modern production equipment, a business owner, as a rule, expects to increase sales volumes, as well as improve the quality of products. Efficient use of fixed assets helps to improve technical and economic indicators, reduce production costs and, as a result, increase profits.

In the process of carrying out business activities, there are risks of theft and inefficient use of fixed assets. In practice, it can be quite difficult to find the culprit and withhold from him the amount of damage caused [1]. In such a situation, the company will have 82 to cover this loss at its own expense. Accordingly, special attention is paid to the organization of accounting and effective control of assets [2-5]. The organization of internal control will reduce the above risks, as well as ensure compliance with the requirements of the current legislation. The Law on Accounting provides for the obligation to organize and implement internal control of accounting and preparation of accounting (financial) statements for those economic entities that are subject to mandatory audit ${ }^{1}$.

When organizing control measures, the internal controller must also take into account the increasing importance of the audit of financial statements. Since 2020 , if an audit is mandatory for an enterprise, then in the corresponding field of the balance sheet it is necessary to make a note about this and indicate information

${ }^{I}$ Federal Law of December 6, 2011 No. 402-FZ "On Accounting”. 


\section{Agrarian Bulletin of the Urals No. 02 (217), 2022}

about the audit organization (individual auditor) $)^{2,3,4}$. Incorrect reporting may not allow obtaining an audit report that will have a positive value from the point of view of potential investors and banks [8].

Makes its own adjustments to accounting and a new standard for fixed assets. In 2022, FAS 6/2020 and FAS 26/2020 become mandatory for application, so it will be necessary to revise the criteria for classifying assets as fixed assets, limits, useful lives, depreciation groups. Particular attention should be paid to changes in the accounting of industrial and agricultural enterprises, which, as a rule, have a significant amount of fixed assets in the property.

The purpose of internal control of property, plant and equipment is to ensure that assets are acquired in the most economical way, that they are physically preserved, that they are maintained in working condition, and that that assets are disposed of at the most favorable price. Based on the purpose, the tasks of internal control should include [9]:

- the acquisition of fixed assets should not be carried out without the consent of the head of the enterprise;

- ensuring the correct assessment of the value of assets in the organization's accounting;

- conducting analytical accounting for individual inventory items;

The main issues of organizing internal control of fixed assets
- timely inventory in order to protect against theft, abuse, accidental death;

- registration of the disposal of fixed assets with the relevant documents, with the mandatory approval of the head.

\section{Methods}

In the course of the study, general scientific research methods (synthesis, system method, structural method) were used. Regulations, clarifications of regulatory authorities, judicial practice were studied, according to the results of the study, systematized verification algorithms were proposed

\section{Results}

The main areas that the internal controller should pay attention to when organizing control over fixed assets (Fig. 1).

Increased attention from the internal controller requires checking the safety of fixed assets. The main method by which the safety of objects is checked is inventory $[9 ; 10]$. With its help, control over the safety of assets is carried out, including a comparison of the actual availability of objects with accounting data. If deviations are found, it is necessary to obtain explanations from the responsible persons. In the course of the inventory, the correctness of the assignment of inventory numbers is also revealed. For example, inventory numbers of retired fixed assets cannot be assigned to other newly incoming objects.

\footnotetext{
${ }^{2}$ Federal Law of December 30, 2008 No. 307-FZ "On Auditing".

${ }^{3}$ Federal Law of August 3, 2018 No. 303-FZ "On amendments to Certain Legislative acts of the Russian Federation on taxes and fees".

${ }^{4}$ Order of the Ministry of Finance of the Russian Federation of April 19, 2019 No. 61n "On Amendments to the Order of the Ministry of

Finance of the Russian Federation of July 2, 2010 No. 66n "On Forms of Accounting Statements of Organizations".
} 
The internal controller should pay attention to the quality of the inventories conducted by the enterprise. For this, documentary control is carried out [11]:

- observance of terms and order of inventory;

- the order of summing up;

- decisions to resolve the identified discrepancies;

- the correctness of the reflection of the results of the inventory on the accounts of accounting.

Control must be organized taking into account signs of possible violations and typical errors [12; 13].

Documents drawn up upon receipt of fixed assets by the enterprise may contain the following violations:

- the dates of drawing up acts of commissioning precede the dates of acquisition of fixed assets;

- the accounting unit of fixed assets is incorrectly defined;

- one inventory object is counted as several. Accounting for each part of the same item is possible only if their useful lives are significantly different. The accounting policy should fix the criterion of materiality of terms of use $\mathrm{e}^{5,6}$.

It should be borne in mind that employees can redistribute the value of the asset among the individual parts in the right way, namely: assign the main part of the cost to some auxiliary devices, and make the necessary liquid parts very cheap, in order to subsequently sell (transfer) to the right organization. To exclude such a situation, it is necessary to check the documents of the equipment supplier, which contain a list of equipment with sales prices.

Increased control is recommended to be given to asset misappropriation fraud schemes that have been identified in the practice of enterprises in order to reduce the risk of damage to the enterprise. In practice, such schemes are the following operations:

- purchase/sale of fixed assets on conditions known to be unfavorable for the company in order to receive remuneration;

- use of fixed assets for personal purposes, in particular, for the production of products, obtaining a loan secured by them, etc.;

- transfer of fixed assets for rent, collateral on unfavorable terms for the company, which may subsequently lead to their loss if the terms of the collateral are not met;

- making fixed assets as a contribution to the authorized capital of third parties affiliated with management, which involves the transfer of fixed assets to the balance of another person and the loss of this property by the company;

- early unjustified write-off of fixed assets and their further sale to persons affiliated with management or use for personal purposes;

${ }^{5}$ Order of the Ministry of Finance of the Russian Federation of September 17, 2020 No. 204n "On approval of Federal Accounting Standards FAS 6/2020 "Fixed Assets" and FAS 26/2020 "Capital Investments".

${ }^{6}$ Order of the Ministry of Finance of the Russian Federation of October 13, 2003 No. 91n "On approval of Methodological guidelines on accounting of fixed assets".
- transfer of fixed assets for safekeeping to third parties affiliated with the management, and their further use for personal purposes, etc.

Errors made in the formation of the initial cost of fixed assets may lead to a distortion of the cost, residual value of fixed assets, debt to the budget for property taxes and profits of the organization as of the reporting date. In accordance with the FSB, fixed assets in accounting upon recognition are valued at their original cost, which is determined as the amount of capital investments in the object [14].

To reduce the risk of fraud in the purchase / sale of fixed assets on terms that are obviously unfavorable for the enterprise in order to receive remuneration, verification should be carried out using documentary control methods. It is necessary to make sure that the cost is formed in accordance with the documents received from the supplier. The initial cost of the object, in accordance with the norms of the current legislation, should include ${ }^{7}[15 ; 16]$ :

- the value of the asset determined by the contract and payable to the supplier;

- the value of assets written off or depreciable in connection with their use in capital investments;

- salary accrued to employees taking part in the implementation of capital investment, taking into account deductions for compulsory social insurance;

- an appraisal obligation, including for future dismantling, disposal of property and environmental restoration.

Using the inventory lists, it should be established whether all fixed assets have been transferred to employees with whom liability agreements have been concluded. When exercising documentary and actual control, the controller should make sure that there is a list of orders that approved the lists of materially responsible persons. When identifying fixed assets that are not accepted by materially responsible persons, the internal controller checks the availability of these funds and their condition. If it is unsatisfactory, then the guilty persons are identified and their transfer to the financially responsible person is ensured. Objects are checked and protected, for example, the presence of an alarm in the room where objects are stored, the presence of bars on the windows and the operation of security systems.

When checking the movement of fixed assets, you should pay attention to ${ }^{8}[11 ; 13]$ :

- availability and correct execution of all necessary accounting documents (acts, inventory cards, etc.). Entries in fixed asset accounting cards are verified with the data of primary accounting documents. Records

${ }^{7}$ The Tax Code of the Russian Federation (Part Two) of July 19, 2000 No. 118-FZ.

${ }^{8}$ Order of the Ministry of Finance of the Russian Federation of October 31, 2000 No. 94n "On Approval of the Accounting Plan of Financial and Economic activities of organizations and Instructions for its Application". 


\section{Agrarian Bulletin of the Urals No. 02 (217), 2022}

in inventory cards should be compared with technical data sheets. Inventory cards are checked in total against synthetic accounting data. If discrepancies are found in accounting registers or technical documentation, they should be corrected;

- if any fixed assets are taken or leased, then this should be reflected in off-balance accounts 001 "Leased fixed assets" (from the lessee) and 011 "Fixed assets leased" (from the lessor).

All facts of untimely posting of fixed assets are revealed. Such facts may indicate the use of fixed assets for the production of unaccounted for products, use for personal purposes, etc. [11].

The controller is advised to verify the actual operation of the accepted fixed assets. In practice, cases of posting of newly constructed buildings were revealed, the cost of which included the cost of the actually stolen equipment. To identify such violations, the data of the inspection of objects in kind should be compared with the data reflected in the act of acceptance and transfer of fixed assets. The correctness of the receipt of newly created objects is determined by comparing the objects accepted for accounting with the information indicated in the title list, estimate. The cost of imperfections identified during the acceptance of the constructed object should be attributed to the increase in cost, and not to costs [11].

When controlling the acquisition of new equipment, they check the completeness of accounting for sets of spare parts, tool kits.

Fixed assets with a low cost can occupy a significant part in the structure of the company's assets. To reduce the burden on the accounting system of an enterprise, from 2022, you can use the FAS 6/2020 norm and not keep records of fixed assets with such a value. Write off the costs of their acquisition as expenses at a time in the period in which they arose. In the accounting policy of the enterprise for accounting purposes, it is necessary to set a limit on the value of fixed assets, taking into account information about their materiality. Recall that for the purposes of tax accounting, fixed assets include property with an initial value of more than 100,000 rubles (art. 257 (1) of the Tax Code of the Russian Federation). It is possible to assume that the establishment of the same limit on the value of fixed assets in accounting and tax accounting will allow avoiding the accrual of deferred taxes.

On the one hand, the advantages of this approach are obvious, but having written off the cost of low-value fixed assets to the expenses of the current period, the enterprise needs to ensure proper control over their safety. Firstly, such a requirement is established in the FAS (art. 5 of FAS 6/2020), i. e. it will be necessary to organize the accounting of fixed assets for the balance sheet. Secondly, to reduce the risk of theft and fraud by employees of the organization. Third, when a significant number of such items are used in an entity's activities, information about the totality of values may be material to users of financial statements. In particular, from the point of view of potential investors, an enterprise with a high share of fixed assets is more attractive and reliable. If the organization plans to receive borrowed funds, then the net assets indicator is important.

The useful life (hereinafter referred to as the SPI) of an item of fixed assets when accepting an item for accounting is determined by the organization independently.

When the SPI objects are installed, the classifications of fixed assets included in the depreciation groups can be identified ${ }^{9}$. Please note that the SPI according to FAS 6/2020 depends on the expected:

- period of operation;

- physical wear and tear, taking into account the mode of operation, the system for carrying out repairs;

- obsolescence, for example, as a result of changes in market demand for finished products or services;

- plans for replacement and modernization, technical re-equipment.

\begin{tabular}{|l|l|}
\hline $\begin{array}{l}\text { Depreciation } \\
\text { check }\end{array}$ \\
$\qquad \begin{array}{l}\text { The legality of assigning fixed assets to the corresponding } \\
\text { depreciation groups is established }\end{array}$ \\
$\begin{array}{l}\text { Legality of Suspension of Depreciation for Tax Accounting } \\
\text { Purposes } \\
\text { decreasing coefficients to the basic rate of depreciation }\end{array}$ \\
$\begin{array}{l}\text { asset object, the correctness of the revision of the SPI } \\
\text { indirect expenses for income tax purposes }\end{array}$ \\
\hline
\end{tabular}

Fig. 2. Algorithm for checking accrued depreciation

${ }^{9}$ Decree of the Government of the Russian Federation of January 01, 2002 No. 1 "On the Classification of fixed Assets Included in depreciation groups". 
When checking depreciation, it is necessary to establish whether individual fixed assets are correctly assigned to the corresponding groups according to depreciation rates. The amount of accrued depreciation affects the cost of production, incl. for the purposes of tax accounting for income tax, as well as for the calculation of property tax. Due to the fact that in the new FAS 6/2020 the concept of "book value" is given, and the concept of "residual value" is absent, we will clarify the definition of the tax base for property tax [14] To calculate the taxable base for property tax, deduct depreciation and depreciation from the purchase price of a fixed asset and add the cost of investments related to the improvement and (or) restoration of objects. The internal controller can use the following depreciation check algorithm (Fig. 2).

When checking, the specifics of production should be taken into account $[2 ; 7]$. In particular, at agricultural enterprises until the end of 2021 for accounting purposes, depreciation is charged during the season. For example, the activity was carried out 6 months a year, respectively, it was necessary to write off $1 / 6$ of the annual depreciation rate during the 6th season. There is no such rule in FAS 6/2020, i. e. the frequency of depreciation is not regulated, the organization has the right to choose the most suitable depreciation option for itself.
There are also some features of depreciation accounting, which must be taken into account when checking, in tax accounting. As a rule, when calculating income tax, the taxpayer must take into account depreciation on fixed assets used directly in the production process as part of direct expenses. And accordingly, distribute it to sold products, work in progress, the balance of finished products, the balance of shipped, but unsold products. However, in practice, and this is also confirmed by arbitration practice, the taxpayer can justify the need to classify depreciation costs as indirect, taking into account the production specifics of the enterprise $^{10}$. According to the court, the list of expenses that should be attributed to direct expenses is not closed. In the accounting policy, the organization may specify the criteria for classifying expenses as direct or indirect. In particular, for production equipment used simultaneously in the manufacture of a wide range of products (when fulfilling various orders), especially if the specifics of production do not allow determining the operating time of a particular machine for the manufacture of a particular product, then depreciation can be included in indirect expenses. Thus, depreciation on equipment used simultaneously in the production of several types of products can be recognized as an indirect expense.

For property to be considered depreciable, it must be used to generate income. It should also be borne in mind that in the event of a temporary lack of income from the use of depreciable property in the organization, depreciation does not stop ${ }^{11}$.

\begin{tabular}{|l|l|}
\hline Repair of fixed \\
assets
\end{tabular}

Fig. 3. Algorithm for checking repair costs

\footnotetext{
10 Resolution of the AC of the Moscow District of March 10, 2020 on case no. A41-12948/2019.

11 Letter of the Department of Tax and Customs Policy of the Ministry of Finance of the Russian Federation of April 27, 2020 No. 03-03$06 / 1 / 34012$ "On the accrual of depreciation in respect of fixed assets held for sale".
} 


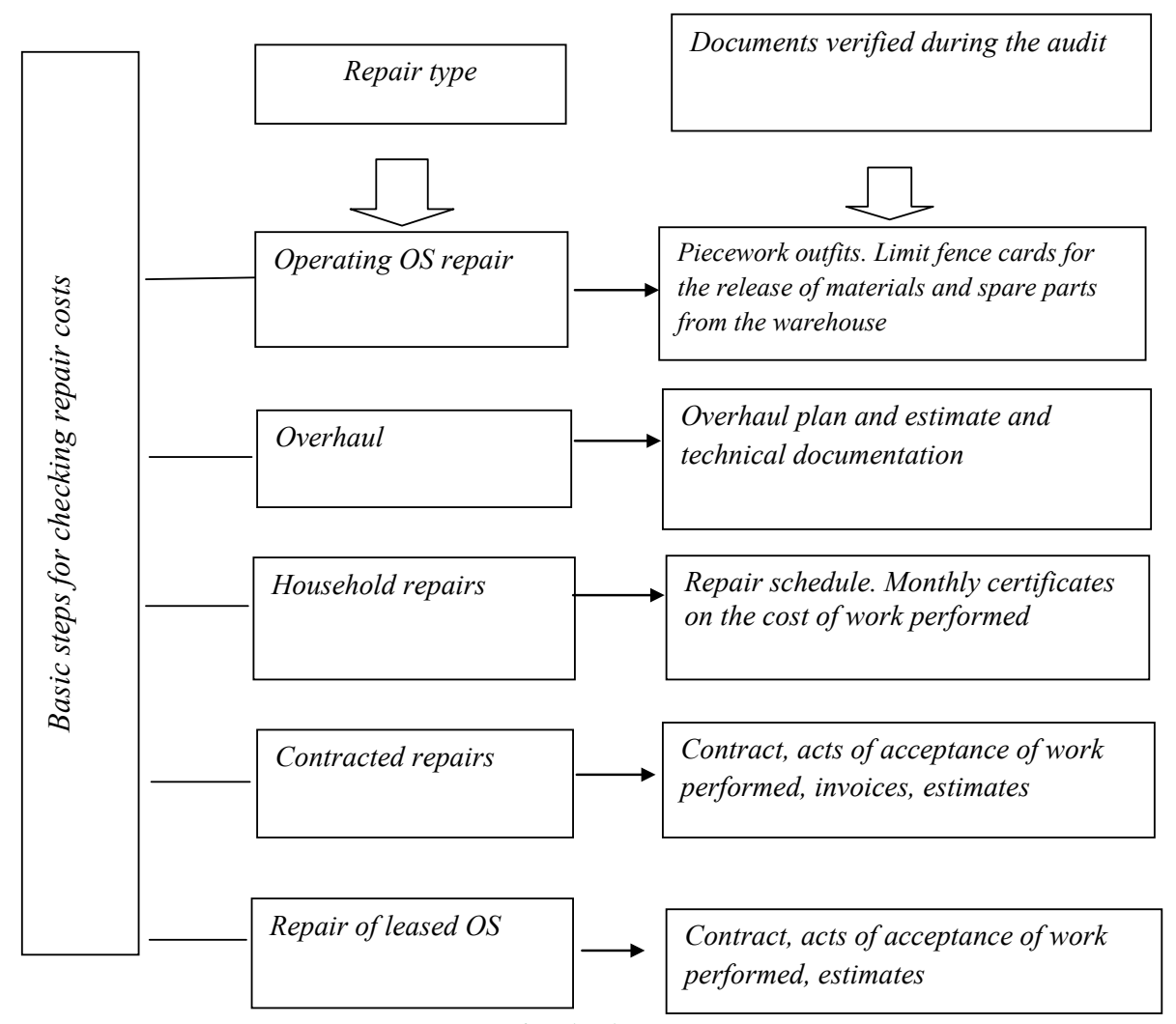

Fig. 4. Steps for checking repair costs

To keep assets in working condition, it is necessary to carry out systematic and timely repairs. The organization must draw up annual, quarterly and monthly plans for repair work, which are approved by the head. Fixed assets to be repaired undergo a preliminary examination by representatives of engineering and technical personnel.

The algorithm for checking repair costs can be represented as follows (Fig. 3).

It is necessary to clarify in what way the repair was carried out, contract, economic or mixed, in order to verify supporting documents. In particular, when checking current repair operations, on the basis of orders and limit-fence cards for the release of goods and materials from the warehouse, they determine the correctness of payroll and the expenditure of materials and spare parts. Repairs carried out by an economic method must be verified through a survey of facilities and ensure the actual use of parts, assemblies, assemblies in the specified scope of work performed, as well as the reliability of the information reflected in the monthly certificates of the cost of work performed on the overhaul of each asset [17]. The main types of repairs, as well as the documents required for verification, are shown in the Fig. 4.

When checking operations for accounting for repair costs, attention is paid to the correctness of attributing work to current or capital repairs, which are accounted for as part of other income tax expenses. If after the repair there was a change in the main technical characteristics or the purpose of the object being repaired, then such changes will be regarded as modernization (reconstruction), the cost of which will change the original cost of the object (art. 257 (2) of the Tax Code of the Russian Federation).

As judicial practice shows, tax authorities quite often reclassify major repairs into reconstruction.

During the inspection, it was found that the organization carried out work on the repair of railway tracks and the replacement of switches, as a result of which the rails were replaced with a more improved brand, which, according to the IFNS, led to an increase in the capacity of railway tracks. The cost of work on the reconstruction of the railway tracks of the shunting area and switches changes the initial value of the objects of depreciable property, therefore, should be written off as part of expenses by depreciation.

At the time of the work, the railway tracks were physically worn out, unsuitable for further operation of fixed assets (created in 1960), with a residual value of 0 rubles. Therefore, the courts concluded that, in fact, the construction of a new railway track took place on the site of obsolete, physically worn out and unusable fixed assets. According to the results of the audit, additional income tax and property tax were assessed ${ }^{12}$.

Attention should be paid to the changes introduced by the new FAS 6/2020, if the organization's costs for repairs, technical inspection, maintenance with a fre-

\footnotetext{
${ }^{12}$ Definition of the Armed Forces of the Russian Federation of December 12, 2019 No. 303-ES19-22337.
} 


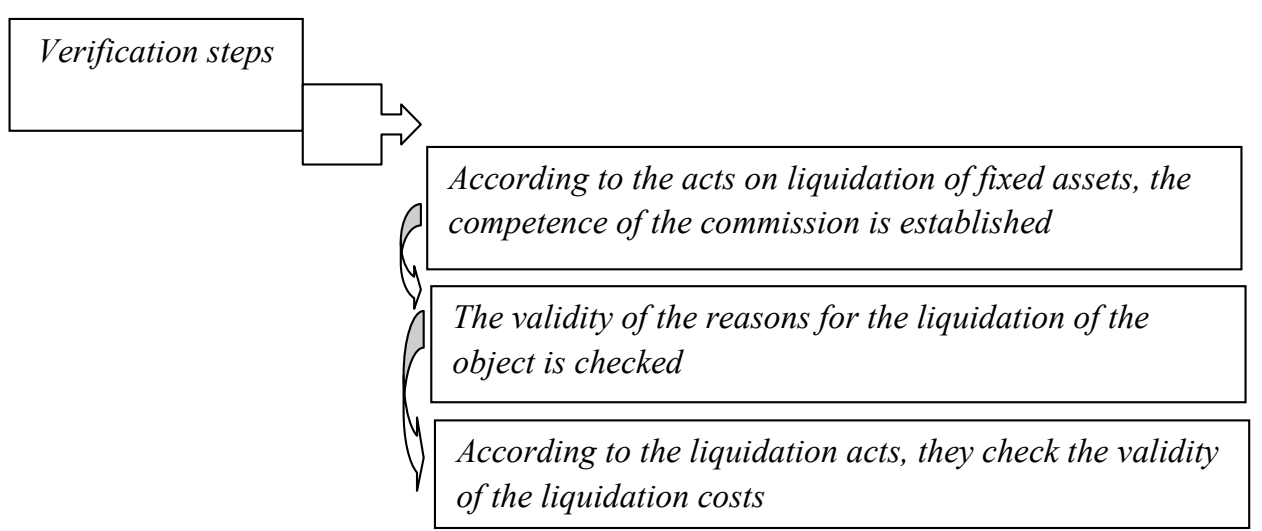

Fig. 5. Stages of verification of documents confirming the liquidation of fixed assets

quency of more than 12 months or more than the usual operating cycle exceeding 12 months are recognized as significant in value, then they should be recognized as an independent inventory object.

The following facts help to establish the quality of the major repairs carried out:

- long-term trouble-free operation of the fixed assets after repair,

- reduction of downtime,

- reduction of maintenance costs,

- compliance with the inter-repair periods.

Operations on the disposal of fixed assets require attention from the internal controller [18; 19]. Based on the results of the audit, an analysis of the disposal of fixed assets is carried out and conclusions are drawn about the economic feasibility of disposal, the correctness of reflecting transactions for the purposes of accounting and tax accounting on the disposal of fixed assets.

Documents on objects liquidated before the expiration of the established service life must be carefully studied in order to identify the perpetrators of the premature failure of the object, as well as the competence of the persons included in the liquidation commission. The stages of checking the liquidation of fixed assets are shown in Fig. 5. One of the significant errors will be the lack of documents confirming the liquidation of the fixed asset.

A separate check requires the possibility of using individual units, parts, materials of the decommissioned object, whether the assessment of units, scrap metal and precious metals was carried out correctly (weight, delivery to the appropriate warehouse, whether they were entered into accounting accounts).

Let's pay attention to one more change of the FAS, this is the introduction of the concept of "liquidation value". Salvage value - the amount that the company will receive after the end of depreciation and writeoff of the object, for example, in the form of materials, scrap metal, etc. The correctness of the formation of the salvage value should also be checked during the audit process.

The organization of an effective internal control system, as well as the development of the Regulation on the maintenance of the internal control system of fixed assets, will allow, including the enterprises of the agricultural sector, to preserve assets. As well as:

- to stop the facts of untimely and incomplete capitalization of fixed assets;

- track how fully the capacity of the equipment is used;

- exclude the posting of newly built facilities, the cost of which includes the cost of actually stolen equipment;

- prevent unreasonable liquidation and sale of objects at reduced prices.

An effective internal control system allows you to competently organize accounting and accounting for tax purposes, which will reduce the risks of additional tax charges in the event of an audit by regulatory authorities.

\section{References}

1. Panferova L. The importance of internal control for agricultural organizations and ways to improve it // E3S Web of Conferences. Ekaterinburg, 2020. DOI: 10.1051/e3sconf/202022206025. (In Russian.)

2. Karmatskikh D. M., Roznina N. V., Karpova M. V. Osnovnye sredstva kak neot"emlemaya chast' proizvodstvenno-khozyaystvennoy deyatel'nosti i effektivnost' ikh ispol'zovaniya [Fixed assets as an integral part of production and economic activities and the efficiency of their use] // Topical Issues of the Modern Economy. 2019. No. 5. Pp. 405-411. (In Russian.)

3. Kol'tsova T. A., Kuryleva V. A. Nezavershennoe stroitel'stvo kak ob"ekt ucheta i otchetnosti [Construction in progress as an object of accounting and reporting] // Prioritetnye napravleniya regional'nogo razvitiya: sbornik statey po materialam II Vserossiyskoy (natsional'noy) nauchno-prakticheskoy konferentsii s mezhdunarodnym uchastiem (25 fevralya 2021 g.) Kurgan, 2021. Pp. 146-151. (In Russian.) 


\section{Agrarian Bulletin of the Urals No. 02 (217), 2022}

4. Nikulina S. N. Vnutrenniy kontrol' ucheta osnovnykh sredstv [Internal control of accounting of fixed assets] // Topical Issues of the Modern Economy. 2021. No. 5. Pp. 681-687. (In Russian.)

5. Kurulenko T. A. Organizatsiya i otsenka sostoyaniya vnutrennego kontrolya osnovnykh sredstv [Organization and assessment of the state of internal control of fixed assets] // Bukhgalterskiy uchet i analiz. 2021. No. 10 (298). Pp. 36-40. (In Russian.)

6. Akhtemova A. R. Osnovnye napravleniya sovershenstvovaniya vnutrennego kontrolya osnovnykh sredstv predpriyatiya [The main directions of improving the internal control of fixed assets of the enterprise] // Aktual'nye problemy bukhgalterskogo ucheta, analiza i audita: materialy XIII Vserossiyskoy molodezhnoy nauchno-prakticheskoy konferentsii s mezhdunarodnym uchastiem, Kursk, 2021. Pp. 44-46. (In Russian.)

7. Sverdlova Yu. O., Popov V. P. Provedenie vnutrennego kontrolya osnovnykh sredstv v sel'skokhozyaystvennykh organizatsiyakh [Internal control of fixed assets in agricultural organizations] // Problemy i perspektivy razvitiya ekonomicheskogo kontrolya i audita v Rossii: sbornik statey po materialam IX Vserossiyskoy nauchno-prakticheskoy konferentsii molodykh uchenykh. Krasnodar, 2018. Pp. 148-152. (In Russian.)

8. Dombrovskaya E. N. Risk-Based Internal Control over Formation of Financial Reporting // Integrated Science in Digital Age 2020. Cham, Switzerland: Springer Nature Switzerland, 2020. Pp. 42-52.

9. Kvasova A. A., Ovchinnikova O. A. Oshibki i riski v uchete osnovnykh sredstv i sistema vnutrennego kontrolya kak mera ikh predotvrashcheniya [Errors and risks in the accounting of fixed assets and the internal control system as a measure of their prevention] // Novaya nauka: istoriya stanovleniya, sovremennoe sostoyanie, perspektivy razvitiya: sbornik statey Mezhdunarodnoy-prakticheskoy konferentsii. Ufa, 2020. Pp. 66-69. (In Russian.)

10. Takhtomysova D. A. Inventarizatsiya kak osnova vnutrennego kontrolya dvizheniya i sokhrannosti osnovnykh sredstv [Inventory as the basis for internal control of movement and safety of fixed assets] // Tsifrovye effekty razvitiya rossiyskoy ekonomiki: materialy III vserossiyskoy (natsional'noy) nauchno-prakticheskoy konferentsii. Engels, 2021. Pp. 85-87. (In Russian.)

11. Reviziya i kontrol': uchebnik [Revision and control: a textbook] / M. V. Mel'nik, A. S. Panteleev, A. L. Zvezdin. Moscow: Knorus, 2009. 640 p. (In Russian.)

12. Makarenko S. V., Stukonozhenko Zh. V. Vnutrenniy kontrol' osnovnykh sredstv: tipichnye oshibki i metodika ikh vyyavleniya [Internal control of fixed assets: typical mistakes and methods for their detection] // Innovative development of economy. 2018. No. 1 (43). Pp. 319-328. (In Russian.)

13. Ovechkina Yu., Bulycheva A. Vnutrenniy control' osnovnykh sredstv [Internal control of fixed assets] // International independent scientific journal. 2020. No. 20. Pp. 20-23. (In Russian.)

14. Eliseeva O. V. Uchet osnovnykh sredstv v sootvetstvii s novym Federal'nym standartom FSBU 6/2020 “'Osnovnye sredstva" [Accounting for fixed assets in accordance with the new Federal Standard FSBU 6/2020 "Fixed Assets"] // Vestnik of the Russian University of Cooperation. 2021. No. 1 (43). Pp. 34-38. (In Russian.)

15. Methodological basis of internal control in the costs management system of enterprises / G. Klychova, A. Zakirova, A. Khusainova [et al.] // E3S Web of Conferences: 14. Rostov-on-Don, 2021. DOI: 10.1051/e3sconf/202127310040. (In Russian.)

16. Oleynik M. A., Alekseenko A. Yu. Sovershenstvovanie bukhgalterskogo ucheta i vnutrennego kontrolya osnovnykh sredstv [Improving accounting and internal control of fixed assets] // Natural humanitarian studies. 2021. No. 36 (4). Pp. 310-317. (In Russian.)

17. Parushena N. V., Kyshtymova E. A. Audit: osnovy audita, tekhnologiya i metodika provedeniya auditorskikh proverok: uchebnoe posobie [Audit: the basics of audit, technology and methods of conducting audits]. Moscow: Forum, 2013. 560 p. (In Russian.)

18. Shtam A. O. Vnutrenniy kontrol' operatsiy po postupleniyu i vybytiyu osnovnykh sredstv [Internal control of operations for the receipt and disposal of fixed assets] // Young Scientist. 2020. No. 22 (312). Pp. 412-414. (In Russian.)

19. Gorin O. A. Sovershenstvovanie metodiki vnutrennego kontrolya postupleniya ob"ektov osnovnykh sredstv predpriyatiya [Improving the methodology of internal control of the receipt of objects of fixed assets of the enterprise] // Problemy i perspektivy razvitiya kooperatsii i integratsii v sovremennoy ekonomike: sbornik statey I Mezhdunarodnoy nauchno-prakticheskoy konferentsii. Engels, 2018. Pp. 115-118. (In Russian.)

\section{Authors' information:}

Tatyana V. Zyryanova ${ }^{1}$, doctor of economic sciences, professor of the department of accounting and audit, ORCID 0000-0003-0146-247X, AuthorID 328866; +7 922 10-29-139, tatyana.vlad.zyr@yandex.ru Elena V. Manakova ${ }^{2}$ candidate of economic sciences, associate professor of the department of economic theory, ORCID 0000-0002-2416-6895, AuthorID 550787; +791262-00-664,manakova.elena@inbox.ru

${ }^{1}$ Ural State Agrarian University, Ekaterinburg, Russia

${ }^{2}$ Ural Institute of Management - the branch of the Russian Presidential Academy of National Economy and Public Administration, Ekaterinburg, Russia 